\title{
Expresión y tropismo del Herpesvirus de Ostreidos tipo 1 en dos tejidos del ostión del Pacífico Crassostrea gigas
}

\author{
Expression and Tropism of the Ostreid Herpesvirus 1 in two tissues of the \\ Pacific oyster Crassostrea gigas
}

\author{
Carolina Gallardo-Ybarra, Christian Minjarez-Osorio, José Manuel Grijalva-Chon, Reina Castro-Longoria, Manuel \\ Adolfo Lastra-Encinas, Enrique De-la-Re-Vega* \\ Departamento de Investigaciones Científicas y Tecnológicas. Universidad de Sonora, Encinas y Rosales s/n. Hermosillo, \\ Sonora.
}

\section{RESUMEN}

El Herpesvirus de Ostreidos-1 (OsHV-1), causa altas mortalidades en los cultivos de Crassostrea gigas, este ha sido estudiado ampliamente para poder entender su patogénesis, sin embargo, no se ha estudiado donde prefiere replicar sus genes y donde estar como un virus activo. El objetivo del presente trabajo fue evaluar la expresión (ARNm) y el gen (ADNg) de la ADN polimerasa viral en dos tejidos de Crassostrea gigas infectado experimentalmente. Se realizó un bioensayo de infección y se tomaron muestras de tejidos para extraer ADN y ARN, a diferentes horas post infección. Los cambios en la expresión del gen de la ADN polimerasa se evaluaron por qPCR y por histología se detectaron los cambios en la estructura de los tejidos. Los resultados indican que el OsHV-1 replica su ADN en células del tejido de branquia, ya que se detectó el mensaje de la ADN polimerasa 59 veces más que el gen. Mientras que en las células de manto se cuantificó el gen 31 veces más que la expresión del mensaje del ORF100. Lo que sugiere un tropismo del OsHV-1, primero por las células del tejido de branquias en las cuales replica su ADN y seguido de las células del tejido de manto en el cual se encuentra como virus activo.

Palabras clave: Herpesvirus de ostreidos-1, OsHV-1, Tropismo, Expresión

\section{ABSTRACT}

The Ostreid Herpesvirus-1 (OsHV-1) causes high mortalities in Crassostrea gigas cultures, it has been studied extensively in order to understand its pathogenesis, however, where it prefers to replicate its genes and where to remain as an active virus has not been studied. Therefore, the aim of the present work was to evaluate the expression (mRNA) and the gene (gDNA) of the viral DNA polymerase in two Crassostrea gigas infected tissues. An infection bioassay was performed to collect gill and mantle tissue to extract DNA and RNA at different hours post infection. Changes on the expression of the DNA polymerase gene was quantified by qPCR and changes in tissue were detected by histology techniques. We detected that the OsHV-1 replicates its DNA in gills, since a 59-fold higher expression of the DNA polymerase than the detection of the gene was evident. In mantle cells the virus prefers to be infecting rather than express its DNA evidenced

*Autor para correspondencia: Dr. Enrique De la Re Vega

Correo electrónico: enrique.delare@unison.mx

Recibido: 25 de septiembre de 2018

Aceptado: 5 de marzo de 2019 by a 39-fold increase detected in these tissue. The results obtained suggests that the OsHV-1 replicates its DNA in gills and prefers to be as an active virus in mantle.

Keywords: Ostreid Herpesvirus-1, OsHV-1, Tropsim, Expression

\section{INTRODUCCIÓN}

En México la acuacultura de bivalvos se realiza casi exclusivamente en las costas del Pacífico de Baja California y el Golfo de California y ocupa el cuarto lugar en América Latina después de Chile, Brasil y Perú (Maeda-Martínez, 2008). En la región Noroeste de México, el cultivo de moluscos bivalvos es una práctica comercial basada principalmente en el ostión japonés, Crassostrea gigas, en los sistemas estuariolagunares. En los últimos años el cultivo de ostión japonés ha sufrido episodios de mortalidades masivas, en los cuales las principales causas son las bacterias, parásitos y virus, siendo el Herpes virus de Ostreidos tipo 1 (OsHV-1), agente causal de las más recientes mortalidades a nivel mundial, ya que puede causar mortalidades en un tiempo de 3 a 10 días (Mineur et al., 2015). Hoy en día este virus es uno de los patógenos más devastadores para la ostricultura, ya que infecta a varias especies de moluscos como, la ostra Portuguesa (Crassostrea angulata), la ostra plana (Ostrea edulis), almeja japonesa (Ruditapes philippinarum), almeja fina (Ruditapes decussatus), la vieira (Pecten maximus) y el ostión del japonés (Crassostrea gigas) (Renault y Novoa, 2004; Novoa y Figueras, 2012).

El OsHV-1 está clasificado en el orden Herpesvirales, familia Malacoherpesviridae, Género Ostreavirus, especie Herpesvirus de Ostreidos-1 (Renault y Novoa, 2004). Es un virus de morfología icosaédrica con un diámetro de $120 \mathrm{~nm}$, de doble cadena de ADN y 207 kpb (kilo par de bases). Su genoma contiene 136 genes, de los cuales 124 codifican para proteínas únicas y 12 son marcos de lectura abiertos repetidos (ORF, por sus siglas en inglés) (Arzul et al., 2001; Renault y Novoa, 2004), siendo el marco de lectura 100 (ORF100) el gen que codifica para una ADN polimerasa (ADN pol).

Los genes en la replicación de los virus tipo Herpes se pueden categorizar en tres tipos de genes: genes muy tempranos, como la ARN polimerasa II; genes tempranos, como la ADN polimerasa; y por último los genes tardíos, los cuales codifican para proteínas estructurales del virus (Lamb et al., 
2001; Harness et al., 2014). Por tal motivo, medir el mensaje del ORF100 del OsHV-1 durante la infección viral, proporcionará información sobre el entendimiento de una infección activa, la expresión de genes, los posibles reservorios virales y la diseminación del virus y con esto entender el tropismo y biología de la infección viral presente en $C$. gigas (Burge y Friedman, 2012). Se ha reportado que el gen de la ADN polimerasa del OsHV-1 pudiera ser utilizado como el gen referencia para la detección del OsHV-1 ya que los iniciadores reportados y utilizados para detectar la infección están dando resultados falsos-negativos, lo que es un problema grave (Webb et al., 2007; Burge y Friedman, 2012; Pepin, 2013). Además, el estudio de las ADN polimerasas virales ha tomado una gran importancia, ya que son blanco de diferentes alternativas para el control de la infección viral, tal es el caso del uso de análogos de nucleótidos, los cuales funcionan como terminadores de la replicación del ADN viral y han sido ampliamente utilizados en los virus tipo Herpes que infectan al humano (De Clercq, 2010). En especímenes de $C$. gigas infectados con el OsHV-1, se ha descrito que los tejidos blanco principalmente son el manto, los palpos labiales, las branquias, glándula digestiva y tejido conectivo (Lipart and Renault, 2002; Corbeil et al., 2015; Martenot et al., 2016; Dela-Re-Vega et al., 2017). Aun cuando ya se sabe cuáles son los tejidos que infecta el OsHV-1, se desconoce en qué tejido el virus replica sus genes y en que tejido está ensamblado y así poder diseminarse hacía los demás tejidos. Por lo que el objetivo del presente trabajo fue identificar la expresión y tropismo del ORF100 del OsHV-1 en dos tejidos blanco, branquias y manto de $C$. gigas infectado en condiciones de laboratorio, y así contribuir al entendimiento de la biología infectiva del OsHV-1.

\section{MATERIALES Y MÉTODOS}

\section{Obtención de ostión del Pacífico C. gigas infectado}

Con el propósito de tener un stock viral se obtuvieron 20 organismos juveniles y semilla de Crassostrea gigas de un cultivo comercial, que presentaba altas mortalidades, localizado en el estero Morúa en Puerto Peñasco, Sonora, México ( $\left.31^{\circ} 17^{\prime} 31^{\prime \prime} \mathrm{N}, 113^{\circ} 27^{\prime} 10^{\prime \prime} \mathrm{O}\right)$. Los organismos se transportaron al Departamento de Investigaciones Científicas y Tecnológicas de la Universidad de Sonora (DICTUS) y se les extrajo ADN del tejido de manto, utilizando el kit QIAamp DNA Mini (QIAGEN, USA) siguiendo el protocolo del fabricante. La concentración y pureza del ADN se determinó por el cociente de absorbancias $A_{260} / A_{280}$ en un espectrofotómetro NanoDrop 1000 (Thermo Scientific, Massachusetts, Estados Unidos). Para determinar si estaban infectados con el OsHV1 , se realizó un PCR de punto final utilizando el liofilizado de illustra puReTaq Ready-To-Go PCR Beads (GE Healthcare, USA). Para la mezcla de PCR se agregó por reacción $10.5 \mu \mathrm{L}$ de $\mathrm{H}_{2} \mathrm{O}$ libre de nucleasas estéril, $0.5 \mu \mathrm{L}$ de cada cebador (10 $\mu \mathrm{M})$ y $1 \mu \mathrm{L}$ de templado $(25 \mathrm{ng} / \mu \mathrm{L})$. Los iniciadores utilizados fueron el C2 (5'-CTCTTTACCATGAAGATACCCACC-3'), y C6 (5'-GTGCACGGCTTACCATTTTT-3'), los cuales amplifican un fragmento de 709 pares de bases (pb) (Arzul et al., 2001).
La PCR se realizó en un termociclador DNA Engine Peltier Thermal Cycler (BIO-RAD, USA) bajo las siguientes condiciones: un ciclo a $95^{\circ} \mathrm{C}$ por 5 min, 35 ciclos a $95{ }^{\circ} \mathrm{C}$ por $1 \mathrm{~min}$, $58{ }^{\circ} \mathrm{C}$ por 1 min y $72{ }^{\circ} \mathrm{C}$ por $1 \mathrm{~min}$, y un ciclo a $72{ }^{\circ} \mathrm{C}$ por 10 min. Los productos se analizaron por electroforesis en geles de agarosa al $2 \%$ teñidos con bromuro de etidio (EtBr), y se visualizaron en un foto-documentador DNR BIO-Imaging Systems MiniBIS Pro (BioAmerica, Miami, USA) con luz ultravioleta.

\section{Preparación de inóculo viral}

Para la preparación del inóculo viral, se trabajó con los organismos detectados como positivos colectados en el estero Morúa. Los organismos completos se homogenizaron de manera individual en un mortero con solución salina fisiológica estéril (154 mM NaCl) en relación 2:1 ( $p / v)$. Posteriormente, cada homogenizado se centrifugó a $5000 \times g$ por $20 \mathrm{~min}$. a $4{ }^{\circ} \mathrm{C}$. El sobrenadante se recuperó y filtró por membranas consecutivas de $5 \mu \mathrm{m}, 0.45 \mu \mathrm{m}, 0.22 \mu \mathrm{m}$ (Millipore, Billerica, USA), todo el proceso se realizó en frío (hielo) (De-la-Re-Vega et al., 2017).

\section{Bioensayo}

Para el bioensayo de infección, 54 ostiones $(7.33 \mathrm{~cm}$ $\pm 1.5 \mathrm{~cm}$ de longitud y $28.18 \mathrm{~g} \pm 12 \mathrm{~g}$ ) se aclimataron en tanques de $40 \mathrm{~L}$ por $48 \mathrm{~h}$, a $36 \mathrm{ppm}$ y a una temperatura de $25^{\circ} \mathrm{C}$ con aireación constante y recambios diarios del $100 \%$ del volumen de agua de mar. Los ostiones se alimentaron diariamente con la microalga Chaetoceros sp., a partir de un cultivo con concentración de 600,000 a 800,000 células $/ \mathrm{mL}$. Una vez que los organismos se aclimataron se mantuvieron por 24 horas envueltos en papel húmedo fuera del agua de mar, para, posteriormente, ser sumergidos por 12 horas en una solución al $7 \%$ de $\mathrm{MgCl}_{2}$ y ser anestesiados. Una vez que las valvas de los ostiones estaban abiertas se extrajo un volumen de $50 \mu \mathrm{L}$ de hemolinfa del músculo abductor. La hemolinfa se trató con anitcoagulante en una relación 1:2 (v/v) (Vargas-Albores et al., 1993), seguido se extrajo el ADN con el kit QIAmp DNA Mini and Blood Mini (QIAGEN, USA) y se realizó un $P C R$ punto final con los iniciadores $\mathrm{C} 2 / \mathrm{C} 6$ para corroborar la ausencia del OsHV-1.

Los muestreos del bioensayo se realizaron a las $0.5,6$, $12,24,48$ y 72 horas post infección (hpi). Para realizar la infección experimental se tomaron 42 organismos detectados como negativos a la infección y se dividieron de la siguiente manera: Para cada hpi se tomaron 5 ostiones (anestesiados previamente) y se inyectaron $50 \mu \mathrm{L}$ de inóculo viral en el musculo abductor, 2 ostiones más se inyectaron con $50 \mu \mathrm{L}$ de solución salina fisiológica estéril $(0.9 \% \mathrm{NaCl})$, estos últimos etiquetados como organismos control (De-la-Re-Vega et al., 2017). Los ostiones infectados se mantuvieron en acuarios de $16 \mathrm{~L}$ con agua de mar ( $36 \mathrm{ppm}$ ) y los controles en acuarios de $6 \mathrm{~L}$. El muestreo de los organismos se realizó de la siguiente manera: primero el organismo se disectó longitudinalmente, para obtener dos mitades del mismo organismo de $1.4 \pm$ $0.5 \mathrm{~g}$, de dicha disección, $1.4 \mathrm{~g}$ se colocaron en solución Da- 
vidson para su posterior análisis histológico (Shaw y Battle, 1957). Con el tejido restante se tomaron tres muestras de $250 \mathrm{mg}$ de manto y branquias de cada ostión, los cuales se colocaron en microtubos de $1.7 \mathrm{~mL}$ diferentes y se le añadió una solución dependiendo del análisis que se realizaría con la muestra. A la primera muestra de cada tejido se le añadió $1 \mathrm{~mL}$ de RNAlater RNA Stabilization Reagent (QIAGEN, USA) para la posterior extracción de ARN. A la segunda muestra se le añadieron $80 \mu \mathrm{L}$ de buffer PBS $(137 \mathrm{mM} \mathrm{NaCl}, 3 \mathrm{mM} \mathrm{KCl}$, $8.1 \mathrm{mM} \mathrm{Na}_{2} \mathrm{HPO}_{4^{\prime}} 1.5 \mathrm{mM} \mathrm{KH} \mathrm{PO}_{4^{\prime}} \mathrm{pH}$ 7.4) para su posterior extracción de ADN total y por último a la tercera muestra se le agregó $1 \mathrm{~mL}$ de etanol absoluto, la cual sirvió como resguardo del experimento. Todas las muestras se almacenaron a $-80^{\circ} \mathrm{C}$.

\section{Obtención de ARN y ADN total}

La extracción de ARN total partió de $50 \mathrm{mg}$ de tejido (branquia o manto) guardado en RNAlater, el tejido se transfirió a un tubo nuevo de $1.7 \mathrm{~mL}$ y se le añadió $1 \mathrm{~mL}$ de TriPure Isolation Reagent (Roche, Suiza), se homogenizó manualmente y se siguieron las instrucciones del fabricante. El ARN aislado se almacenó a $-20{ }^{\circ} \mathrm{C}$ para su posterior análisis. La concentración y pureza del ARN se determinó por el cociente de absorbancias $A_{260} / A_{280}$ en un espectrofotómetro NanoDrop 1000 (Thermo Scientific, Massachusetts, Estados Unidos). Para la síntesis de ADN complementario (ADNc), se eliminó el ADN genómico de los extractos de ARN con DNase I (SIGMA-ALDRICH, SainLouis, Missouri, USA), siguiendo el protocolo del fabricante. La síntesis del ADNc se realizó con el kit QuantiTect Reverse Transcription (QIAGEN, USA) como sigue: $1.07 \mu \mathrm{g}$ de ARN en $9.82 \mu \mathrm{L}, 2.14 \mu \mathrm{L}$ de buffer de limpieza de $A D N g$ y $3.04 \mu \mathrm{L}$ de agua libre de RNasa. Las muestras se incubaron por $5 \mathrm{~min}$ a $42{ }^{\circ} \mathrm{C}$ y se transfirieron a hielo. La transcripción reversa (RT) se preparó agregando $1 \mu \mathrm{L}$ de Quantiscript Reverse Transcriptase, $4 \mu \mathrm{L}$ de Quantiscript RT buffer, $1 \mu \mathrm{L}$ de RT Primer Mix y se añadió $14 \mu \mathrm{L}$ del producto de la reacción anterior. Las muestras se incubaron a $42^{\circ} \mathrm{C}$ por 15 min y posteriormente a $95^{\circ} \mathrm{C}$ por 3 min y se almacenaron a $-20^{\circ} \mathrm{C}$ hasta su uso.

La extracción del ADN genómico se realizó con $50 \mathrm{mg}$ de cada tejido (manto y branquia) y se utilizó el kit QIAamp DNA Mini and Blood Mini (QIAGEN, USA) siguiendo las instrucciones del fabricante. Al igual que el ADN complementario el $A D N$ genómico se almacenó a $-20^{\circ} \mathrm{C}$ hasta su uso.

\section{Expresión absoluta del gen de la ADN polimerasa del OsHV-1}

Para la cuantificación absoluta del gen de la ADN polimerasa viral, se realizó una curva estándar partiendo de la amplificación del gen por PCR punto final con el kit Taq DNA Polymerase (QIAGEN, USA) utilizando como templado el ADN extraído del inóculo viral, y los cebadores reportados por De-la-Re-Vega et al. (2017), rtADNpolF (5'-TTGTAGCGTCCAGGGATGTGA-3') y el ADNpolLERv (5'-GGTCACCGAATTTC(ATGTCT-3'), los cuales amplifican un producto de $177 \mathrm{pb}$. Los cebadores están dirigidos al dominio polimerasa de la proteína. El producto amplificado se purificó utilizando el kit QIAquick Gel Extraction (QIAGEN, USA), siguiendo el protocolo del fabricante y se cuantificó en un NanoDrop 1000 Spectrophotometer (Thermo Scientific, Massachusetts, Estados Unidos). La curva estándar se preparó como sigue: se realizaron 6 diluciones seriadas 1:10, partiendo de $9.93 \times$ $10^{10}$ número de copias, en un volumen final de $50 \mu \mathrm{L}$. Para la cuantificación de la expresión absoluta del gen y la curva estándar de la ADN polimerasa, se utilizó la metodología de qPCR. Para la reacción se utilizó el kit FastStart SYBR Green Master mix (ROCHE, Suiza) como sigue: $1 \mu \mathrm{L}$ de cada dilución (curva estándar) o ADNc de cada hora post infección (equivalentes a $50 \mathrm{ng}$ de $\mathrm{ARN}$ ), por triplicado, $0.5 \mu \mathrm{L}$ de cada oligonucleótido (rtADNpolF y ADNpolLERv) a una concentración de $10 \mu \mathrm{M}, 7.5 \mu \mathrm{L}$ de FastStart SYBR Green Master mix y $4.5 \mu \mathrm{L}$ de $\mathrm{H}_{2} \mathrm{O}$ libre de nucleasas, para tener un volumen final de $14 \mu \mathrm{L}$, la reacción se corrió en el equipo LightCycler 480 II (ROCHE, Suiza). Las condiciones de amplificación fueron las siguientes: 1 ciclo a $95^{\circ} \mathrm{C}$ por $10 \mathrm{~min} ; 30$ ciclos de $95^{\circ} \mathrm{C}$ por $15 \mathrm{~s}, 62^{\circ} \mathrm{C}$ por $15 \mathrm{~s}, 72{ }^{\circ} \mathrm{C}$ por $15 \mathrm{~s} ; 1$ ciclo de $72{ }^{\circ} \mathrm{C}$ por $2 \mathrm{~min}$. También se corrió una curva de disociación en un gradiente de 55 a $95^{\circ} \mathrm{C}$ con aumentos de $0.5^{\circ} \mathrm{C}$ cada 3 segundos, para corroborar la especificidad de la amplificación (Mendoza-Cano y SanchezPaz, 2013; De-la-Re-Vega et al., 2017). El número de copias se determinó a partir del producto cuantificado y utilizando la fórmula (http://cels.uri.edu/gsc/cndna.html):

Como controles de la reacción de qPCR se corrieron: el control positivo el cual fue el ADN utilizado en la curva estándar y al control negativo de la reacción se le agregó solo agua estéril a la mezcla de FastStart SYBR Green Master mix.

\section{Análisis histológico de tejidos de C. gigas infectado}

Los tejidos en solución Davidson se colocaron en etanol al $70 \%$ seguido del proceso de deshidratación de acuerdo a lo establecido por Lightner (1996). Posteriormente, las muestras se incluyeron en parafina, para obtener bloques con los cuales se realizaron cortes de $5 \mu \mathrm{m}$ con un micrótomo manual Keede KD-2258. Los cortes se colocaron en un baño de tejido a $45^{\circ} \mathrm{C}$, se colocaron en portaobjetos rotulados $y$, posteriormente, fueron secados. El exceso de parafina se eliminó colocando los portaobjetos en una estufa a $80^{\circ} \mathrm{C}$. Por último, las muestras fueron teñidas por medio de la técnica de hematoxilina de Harris y eosina (Lightner, 1996). Las muestras ya teñidas se montaron con resina Entellan y después se les colocó un cubreobjetos para observarlas con un microscopio óptico equipado con cámara Evos FL Imaging System (Thermo Fisher Scientific, Massachusetts, Estados Unidos).

\section{Análisis estadístico}

Se realizó un análisis de varianza (ANOVA) en rangos de una vía (Kruskal-Wallis) para establecer diferencias entre los niveles de ARNm y de ADN genómico del gen de la ADN polimerasa, de las diferentes horas post infección para cada uno de los tejidos analizados. Posteriormente, se realizó un análisis post-hoc de comparaciones múltiples por pares 
mediante el procedimiento de Dunn para detectar diferencias entre las horas post infección. Para todas las pruebas se utilizaron a un nivel de significancia del 95\% $(p<0.05)$.

\section{RESULTADOS Y DISCUSIÓN}

El OsHV-1 es capaz de infectar todos los tejidos de $C$. gigas y esto puede atribuirse a que el ostión tiene un sistema de circulación abierto, lo que hace que el virus llegue a cada uno de los tejidos del organismo (Arzul et al., 2002; Martenot et al., 2011). Aun cuando se sabe que el primer tejido que infecta el virus es el tejido del manto, hasta el momento no se ha estudiado en que tejido el virus replica su ADN, en cual tiene su genoma ensamblado y estar como un virus activo. Por tal motivo, se cuantificó el mensaje (ARNm) y el gen (ADNg) del ORF100 el cual codifica para una ADN polimerasa viral, en dos de los principales tejidos blanco reportados en la literatura que infecta el OsHV-1, para conocer parte del tropismo y la biología infectiva del OsHV-1.

Para comparar el número de copias virales y observar una diferencia entre el ADNg y ARNm del gen de la ADN pol, se realizó una curva estándar. Se reporta que los valores óptimos de la pendiente de una curva para ser aceptable, están en el rango de -3.2 a -3.5, siendo el ideal -3.32 que representa el 100\% de eficiencia (Bustin, 2000). Como se puede ver en la figura $1 A$, se observa que se obtuvieron valores de fluorescencia similares para cada dilución (seis diluciones), obteniéndose así una eficiencia de la curva estándar del 95.4\% (Figura 1B) y con las curvas de disociación de cada producto generado se observó que ninguna de las diluciones tuvo algún tipo de inespecificidad al detectar solo un pico a una temperatura de disociación de $77.36^{\circ} \mathrm{C}$ (Figura 1C).

Al comparar la cuantificación del número de copias del gen de la ADN polimerasa viral a partir del ADNg que equivaldría a cuantificar el genoma viral y el nivel de expresión del mensaje (ARNm) del gen, se observó que el mensaje del ORF100 a las 6 hpi en manto, se observó 757 veces superior a los niveles del número de copias de la infección. Sin embargo, a partir de las $12 \mathrm{hpi}$, los niveles del gen viral fueron superior al número de transcritos del ORF100, presentando a las 72 hpi hasta 125 veces más el nivel del gen sobre el de trascrito del ORF100 (Fig. 2A). El nivel de infección observado a las 48 hpi en manto, es el más elevado en todo el experimental. Mientras que los niveles de mensaje del ORF100 a las 6 hpi en branquias, fue $\sim 59$ veces más que los niveles de infección. Es hasta las $72 \mathrm{hpi}$, donde los niveles de infección son $\sim 4$ veces superior a los niveles de mensaje del ORF100 (Figura 2B). Estos resultados se pudieron comparar, ya que presentaron una correlación positiva y como se puede observar en la Figura 2, en ambos casos se detectó un aumento tanto de la expresión como la infección a lo largo de las diferentes horas post-infección.

Burge et al. (2012), midieron la expresión del gen de la ADN polimerasa en larvas de ostión del Pacífico infectadas por co-habitación con el OsHV-1, encontrando que el número de copias virales fue más alto en los días 1, 3, 5 y
A)

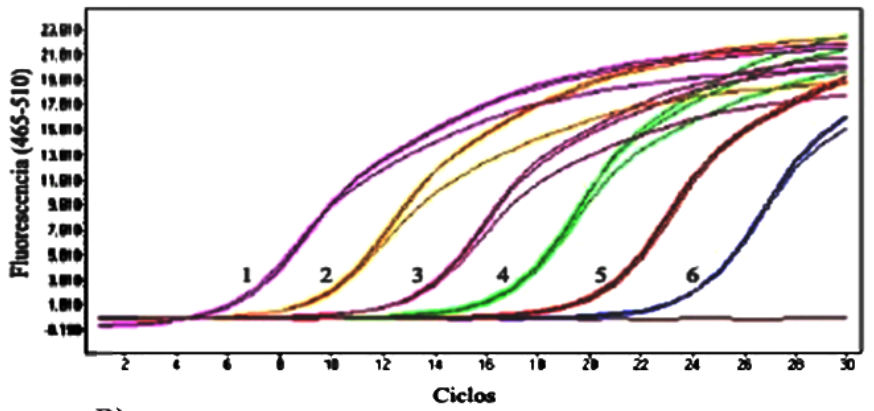

B)

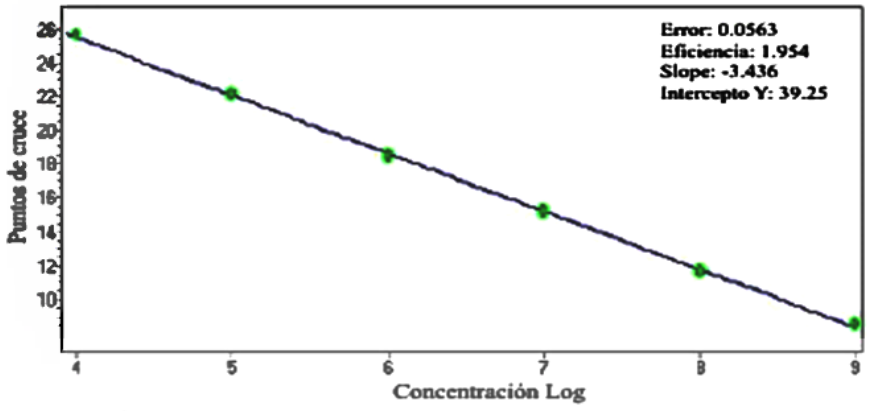

C)

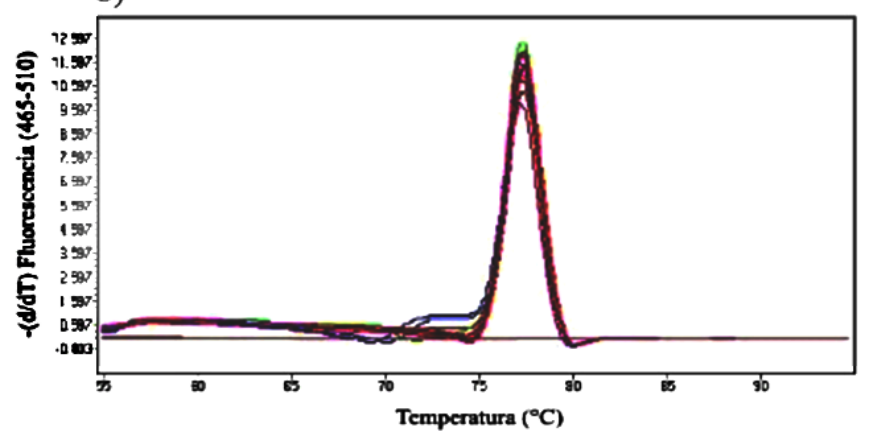

Figura 1. Curva estándar para el ORF100 para determinar carga viral del inóculo y muestras del experimental. A) Señales fluorescentes de las seis diluciones seriadas. De 1-6 se tiene $9.93 \times 10^{8}$ a $9.93 \times 10^{3}$ copias. B) Curva estándar de la concentración de las diluciones seriadas. Eficiencia: $95.4 \%$, pendiente: -3.436. C) Curva de disociación del amplicón del ORF100, temperatura de disociación de $77.36^{\circ} \mathrm{C}$.

Figure 1. ORF100 standard curve, used to determine the copy numbers. A) Dilutions 1-6 fluorescent signals ranging from $9.93 \times 10^{8}$ to $9.93 \times 10^{3}$ copies. B) Standard curve of the dilutions with an efficiency of $95.4 \%$ and a slope of -3.436 . C) Melting curve of a single OsHV-1 DNA polymerase fragment product, melting temperature of $77.6^{\circ} \mathrm{C}$.

7 a diferencia del día 9. Aun cuando la forma de infectar a los ostiones no es la misma, se logró cuantificar la expresión del gen, pero Burge et al. (2012) no lograron identificar en que tejido existe mayor cantidad de virus y en cual el OsHV-1 está replicando su ADN, a diferencia de lo reportado en el presente trabajo. Segarra et al. (2014), reportaron el aumento de transcritos del gen de la ADN polimerasa a partir de las primeras $18 \mathrm{~h}$ después de la infección intramuscular del OsHV-1, lo que contrasta con lo que reporta en el presente trabajo, en donde a las 6 hpi en el tejido de branquia se logró detectar el virus. Por otro lado, Corbeil et al. (2015) reportaron por hibridación in situ y con sondas dirigidas al marco de lectura 4 (ORF4) del OsHV-1, que el virus se encontró en 


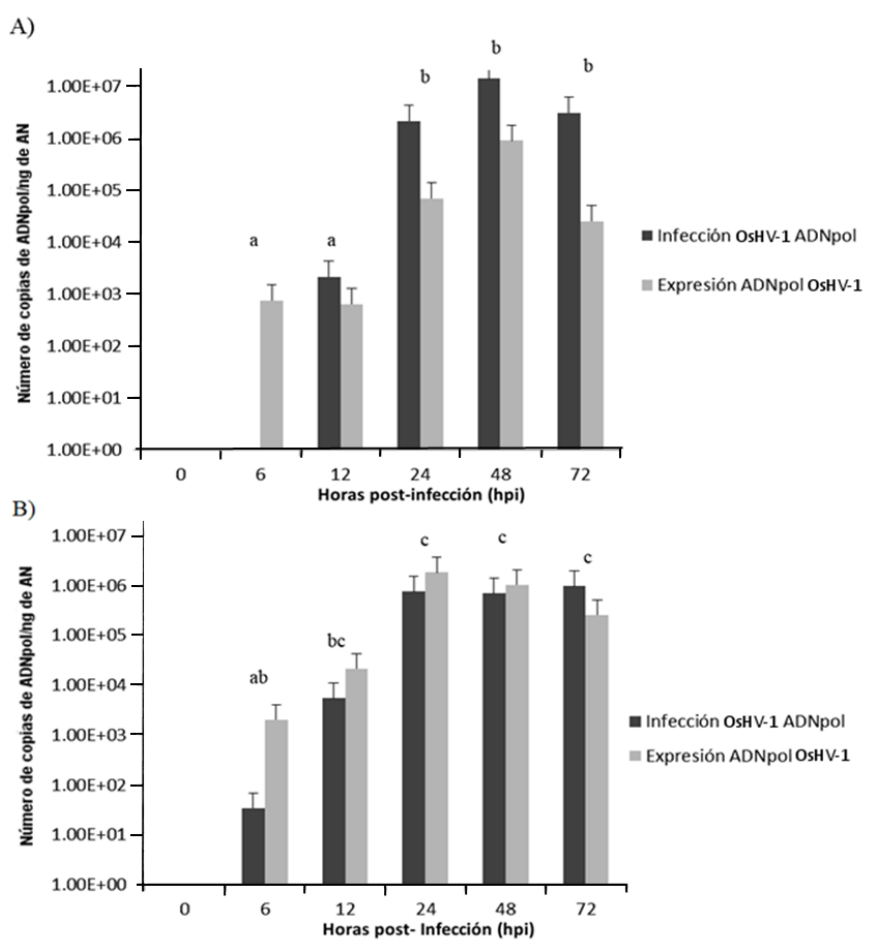

Figura 2. Expresión e infección en A) manto y B) branquias durante la infección experimental de OsHV-1 en Crassostrea gigas. Las literales expresan diferencia significativa $(\mathrm{p}<0.05)$ entre las horas post infección.

Figure 2. Expression and infection in A) mantle and B) gills during the OsHV-1 experimental infection in Crassostrea gigas. Statistical differences are indicated by letters $(p<0.05)$ between each hour post infection.

todos los tejidos del ostión, pero no se logró identificar cual tejido podría ser en el cual el virus está replicando sus genes al inicio de la infección.

Los resultados del presente trabajo también se pueden comparar con otros virus que presentan selección por cierto tipo de células, localizadas en diferentes tejidos del organismo que están infectando. Tal es el caso del Herpes virus de humanos y su selección por células del tipo fibroblastos, neuronales y musculares (Hammerschmidt y Sugden, 1988; Schelhaas et al., 2003); el Lentivirus de ovejas presenta un alto tropismo por macrófagos (Gendelman et al., 1986); el virus de la mancha blanca en camarón y langosta que infecta células del tipo hemocito (Kou et al., 1998; Musthaq et al., 2006); o como el Alphavirus Sindbis en mosquitos que infecta las células de las glándulas salivales (Bowers et al., 1995). En el presente trabajo se identificó que el OsHV-1 replica su ADN en las células de las branquias, mientras que en células de manto se encuentra como virus activo, por lo que en futuros trabajos se pretende encontrar cual tipo de célula sería la que específicamente está infectando el virus.

En los cortes histológicos del tejido de manto de un ostión infectado, se puede observar infiltración hemocítica, pérdida de la estructura tisular y daño severo (Figura 3A y B), mientras que para el organismo control se puede observar el tejido normal y sin lesiones (Figura 3C). En tejido de branquias de organismos infectados, como se puede observar en la Figura 3D y E, conforme va avanzando la infección se observan branquias inflamadas y con pérdida de estructura

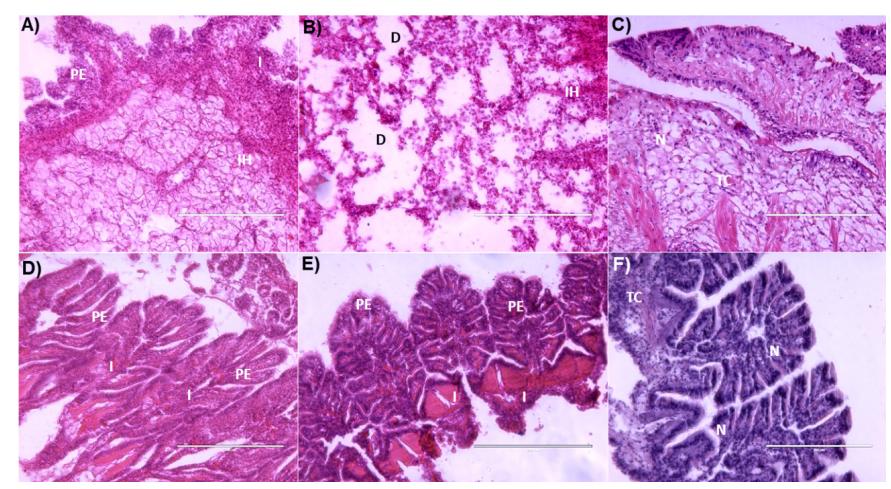

Figura 3. Corte histológico de $5 \mu \mathrm{m}$ de Crassostrea gigas infectado con el OsHV-1 y organismo control, teñidos con la tinción de Hematoxilina-Eosina. A) Manto de un organismo infectado 24 horas. B) Manto de un organismo infectado 48 horas. C) Manto de un organismo control. D) Branquia de un organismo infectado 24 horas. E) Branquia de un organismo infectado 48 horas. F) Branquia de un organismo control. Tejido con inflamación (I), infiltración hemocítica $(\mathrm{IH})$, pérdida de la estructura tisular (PE), Tejido condición normal (N) y tejido conectivo (TC) (Escala: $200 \mu \mathrm{m}$ ).

Figure 3. Five- $\mu \mathrm{m}$ histological section of Crassostrea gigas infected with the OsHV-1 and tissue from a control organism stained with Hematoxilin-Eosine. A) Mantle from a 24 hours infected oyster. B) Mantle section from a 48 hours infected oyster. C) Mantle from a control organism. D) Gill section from a 24 hours infected organism. E) Gill section from a 48 hours infected organism. F) Gill from a control organism. Tissue inflammation (I), haemocitic infiltration (IH), loss of tissular structure (PE), normal tissue (N), connective tissue (TC) (scale bar: $200 \mu \mathrm{m}$ ).

por fusión de apéndice, estos resultados corroboran que la infección viral se dio en los tejidos analizados. Estos resultados histológicos concuerdan con lo ya publicado por diferentes autores en previos estudios (Corbeil et al., 2015; Green et al., 2015; Segarra et al., 2016).

\section{CONCLUSIONES}

En el presente trabajo se identificó que el gen de la ADN polimerasa del OsHV-1 expresa su mensaje en las células del tejido de branquia, mientras que presenta una tendencia por estar como virus activo en el tejido de manto. También se detectó el mensaje del gen a horas tan tempranas de la infección como las 6 horas en tejido de branquias, este es el primer reporte para este tipo de gen en ser detectado a tan tempranas horas post infección, lo que estaría en acorde con trabajos previos en utilizar este gen para detectar la infección en organismos que se encuentran en cultivos y presentan signos de la enfermedad. Así mismo se sugiere que el tejido de branquias podría ser disectado y con ello realizar la detección temprana del virus en ostión. Finalmente, este tipo de estudios aporta información para entender la biología de la infección del Herpes virus de Ostreidos tipo 1 y así poder diseñar estrategias para su control en los cultivos de Crassostrea gigas, como podría ser el uso de análogos nucleosidicos o vacunas de ADN dirigidos a la ADN polimerasa viral.

\section{AGRADECIMIENTOS}

Se agradece a CONACyT por el apoyo financiero de los proyectos 256429, 252979 y ICCMI09841, así como al proyecto PRODEP, USO313001375. 


\section{REFERENCIAS}

Arzul, I., Nicolas, J.L., Davison, A.J., Renault, T., 2001. French scallops: a new host for ostreid herpesvirus-1. Virology 290, 342-349.

Arzul, I., Renault, T., Thébault, A., Gérard, A., 2002. Detection of oyster herpesvirus DNA and proteins in asymptomatic Crassostrea gigas adults. Virus research 84, 151-160.

Bowers, D.F., Abell, B.A., Brown, D.T., 1995. Replication and tissue tropism of the alphavirus Sindbis in the mosquito Aedes albopictus. Virology 212, 1-1.

Burge, C.A., Friedman, C.S., 2012. Quantifying Ostreid herpesvirus (OsHV-1) genome copies and expression during transmission. Microbial ecology 63, 596-604.

Bustin, S.A., 2000. Absolute quantification of mRNA using realtime reverse transcription polymerase chain reaction assays. Journal of molecular endocrinology 25, 169-193.

Corbeil, S., Faury, N., Segarra, A., Renault, T., 2015. Development of an in situ hybridization assay for the detection of ostreid herpesvirus type 1 mRNAs in the Pacific oyster, Crassostrea gigas. Journal of virological methods 211, 43-50.

De-la-Re-Vega, E., Sánchez-Paz, A., Gallardo-Ybarra, C., LastraEncinas, M.A., Castro-Longoria, R., Grijalva-Chon, J.M., LópezTorres, M.A., Maldonado-Arce, A.D., 2017. The Pacific oyster (Crassostrea gigas) Hsp70 modulates the Ostreid herpes virus 1 infectivity. Fish \& Shellfish Immunology 71, 127-135.

De Clercq, E., 2010. In search of a selective therapy of viral infections. Antiviral research 85, 19-24.

Gendelman, H.E., Narayan, O., Kennedy-Stoskopf, S., Kennedy, P., Ghotbi, Z., Clements, J., Stanley, J., Pezeshkpour, G., 1986. Tropism of sheep lentiviruses for monocytes: susceptibility to infection and virus gene expression increase during maturation of monocytes to macrophages. Journal of virology 58, 67-74.

Green, T.J., Rolland, J.-L., Vergnes, A., Raftos, D., Montagnani, C., 2015. OsHV-1 countermeasures to the Pacific oyster's antiviral response. Fish \& shellfish immunology 47, 435-443.

Hammerschmidt, W., Sugden, B., 1988. Identification and characterization of oriLyt, a lytic origin of DNA replication of Epstein-Barr virus. Cell 55, 427-433.

Harness, J.M., Kadar, M., DeLuca, N.A., 2014. Transcription of the herpes simplex virus, type 1 genome during productive and quiescent infection of neuronal and non-neuronal cells. Journal of virology, JVI. 00516-00514.

Kou, G.-H., Peng, S.-E., Chiu, Y.-L., Lo, C.-F., 1998. Tissue distribution of white spot syndrome virus (WSSV) in shrimp and crabs. Advances in shrimp biotechnology 11, 267-271.

Lamb, R.A., Krug, R., Knipe, D., 2001. Fields virology. Fields Virology 1.

Lightner, D., 1996. Handbook of pathology and diagnostic procedures for diseases of penaeid acute viremia (PAV). Fish Pathology 31, 39-45.

Lipart, C., Renault, T., 2002. Herpes-like virus detection in infected Crassostrea gigas spat using DIG-labelled probes. Journal of virological methods 101, 1-10.
Maeda-Martínez, A.N., 2008. Estado actual del cultivo de bivalvos en México. In: Lovatelli, A., A. Farías \& I. Uriarte (Eds). Taller regional de la FAO sobre el Estado Actual del Cultivo y Manejo de Moluscos Bivalvos y su Proyección Futura: Factores que Afectan su Sustentabilidad en América Latina. Actas de Pesca de la FAO. No. 12. Roma, FAO. pp. 91-100.

Martenot, C., Oden, E., Travaillé, E., Malas, J.P., Houssin, M., 2011. Detection of different variants of Ostreid Herpesvirus 1 in the Pacific oyster, Crassostrea gigas between 2008 and 2010. Virus research 160, 25-31.

Martenot, C., Segarra, A., Baillon, L., Faury, N., Houssin, M., Renault, T., 2016. In situ localization and tissue distribution of ostreid herpesvirus 1 proteins in infected Pacific oyster, Crassostrea gigas. Journal of invertebrate pathology 136, 124-135.

Mendoza-Cano, F., Sanchez-Paz, A., 2013. Development and validation of a quantitative real-time polymerase chain assay for universal detection of the White Spot Syndrome Virus in marine crustaceans. Virol J 10, 186-197.

Mineur, F., Provan, J., Arnott, G., 2015 Phylogeographical analyses of shellfish viruses: inferring a geographical origin for ostreid herpesviruses OsHV-1 (Malacoherpesviridae). Marine Biology 162, 181-192.

Musthaq, S.S., Sudhakaran, R., Balasubramanian, G., Hameed, A.S., 2006. Experimental transmission and tissue tropism of white spot syndrome virus (WSSV) in two species of lobsters, Panulirus homarus and Panulirus ornatus. Journal of invertebrate pathology 93, 75-80.

Novoa, B., Figueras, A., 2012. Zebrafish: model for the study of inflammation and the innate immune response to infectious diseases. Current Topics in Innate Immunity II, 253-275.

Pepin Jean-Francois., 2013. Short Technical Report for OsHV-1 detection and quantification by Real Time Polynerase Chain Reaction using OsHV-1 DNA polymerase sequence. RST/LERPC/13-04. https://archimer.ifremer.fr/doc/00137/24814/

Renault, T., Novoa, B., 2004. Viruses infecting bivalve molluscs. Aquatic Living Resources 17, 397-409.

Schelhaas, M., Jansen, M., Haase, I., Knebel-Mörsdorf, D., 2003. Herpes simplex virus type 1 exhibits a tropism for basal entry in polarized epithelial cells. Journal of general virology 84, 2473-2484.

Segarra, A., Baillon, L., Faury, N., Tourbiez, D., Renault, T., 2016. Detection and distribution of ostreid herpesvirus 1 in experimentally infected Pacific oyster spat. Journal of invertebrate pathology 133, 59-65.

Shaw, B.L., Battle, H.I., 1957. The gross and microscopic anatomy of the digestive tract of the oyster Crassostrea virginica (Gmelin). Canadian Journal of Zoology 35, 325-347.

Vargas-Albores, F., Guzmán, M.-A., Ochoa, J.-L., 1993. An anticoagulant solution for haemolymph collection and prophenoloxidase studies of penaeid shrimp (Penaeus californiensis). Comparative Biochemistry and Physiology Part A: Physiology 106, 299-303.

Webb, S.C., Fidler, A., Renault, T., 2007. Primers for PCR-based detection of ostreid herpes virus-1 (OsHV-1): application in a survey of New Zealand molluscs. Aquaculture 272, 126-139. 